\title{
Hydrologic modeling of a treated rangeland watershed
}

\author{
HERBERT B. OSBORN AND J. ROGER SIMANTON
}

\section{Abstract}

The measured runoff from a contour-ripped rangeland watershed is compared with hypothetical runoff based on KINEROS model simulations assuming that the watershed had not been treated. The results indicate that such models as KINEROS can provide a valuable additional tool for evaluation of range treatments and could possibly be used "before the fact" to determine probable water-yield impacts of a rangeland treatment.

Key Words: runoff, rainfall, contour ripping, kinematic

In the western United States only about $40 \%$ of the 160 million hectares of rangeland is considered to be in good or better condition for forage production (USDA 1987). Some methods available to improve forage production are mechanical treatments, vegetation conversion, fertilization, and improved grazing practices. Mechanical treatment and/or vegetation conversion are probably the quickest methods for increasing forage production. Soil ripping and root plowing are 2 common mechanical treatments which have been used extensively in the western United States. However, the hydrologic impact of such treatments has been difficult to evaluate because of a lack of sufficient rainfall and runoff data. Soil ripping effectively reduced surface runoff and erosion during a 3-year study in New Mexico (Dortignac and Hickey 1963). However, Branson et al. (1966) found that ripping decreased perennial grass production and did not significantly decrease runoff from 6 sites in the western United States. In an early study in southeastern Arizona, Simanton et al. (1978) reported reduced runoff for at least the first 5 years following the ripping of a 227-ha watershed in 1965, but felt that the watershed had returned to its pretreatment state by 1975. At that time, only traditional mass curve analyses were available, and the conclusions were considered preliminary. Simanton et al. (1978) also reported no apparent change in the vegetative canopy cover. In a 5-year study in Texas, ripping and/or root plowing reduced runoff appreciably (Richardson et al. 1979).

In this study, a nonlinear, deterministic parameter model [KINEROS (Rovey et al. 1977)] was used, after-the-fact, to analyze the hydrologic effects of ripping a 227-ha rangeland watershed within the Walnut Gulch Experimental Watershed in southeastern Arizona. The KINEROS model was calibrated using characteristics of adjacent instrumented watersheds. This calibrated model was then used to estimate nontreatment responses of a ripped watershed. These nontreatment responses were compared to observed after-treatment responses to determine if the ripped treatment was still effective.

\section{Climate}

In the Southwestern United States, the within-year distribution of precipitation is bimodal, with slow-moving cold fronts supplying the lift for most winter precipitation and convective activity supplying the lift for summer thunderstorm rainfall. Moist tropical air from the Pacific Ocean and/or the Caribbean can flow into

\footnotetext{
Authors are research hydraulic engineer (retired) and hydrologist, USDA-ARS, Aridland Watershed Management Research Unit, 2000 E. Allen Road, Tucson, Arizona 85719.

Manuscript received 28 October 1989.
}

southern Arizona at any time during the year, but is usually concentrated in the summer season from July through early September (Osborn 1968, Osborn and Laursen 1973). The summer season is characterized by widely spaced late afternoon and early evening thunderstorm rains of high intensity, short duration, and limited areal extent. Over $99 \%$ of the annual runoff occurs during the summer rainy season. The moist air flow may be interrupted at any time during the rainy season by a drying period, which introduces an added uncertainty to the occurrence of summer rainfall.

In southeastern Arizona, summer rainfall is the principal and most reliable source of rangeland moisture (Osborn 1968). Within a watershed, rainfall varies both seasonally and annually as well as in both time and space. Local rainfall deficits can occur within a season of average or above-average rainfall over the region.

On Walnut Gulch, average annual rainfall over the watershed has varied from $170 \mathrm{~mm}$ to $378 \mathrm{~mm}$; summer rainfall has varied from $104 \mathrm{~mm}$ to $290 \mathrm{~mm}$; and winter precipitation (including some snow) has varied from $25 \mathrm{~mm}$ to $233 \mathrm{~mm}$ (Osborn 1983). The differences between individual raingages is even greater.

The extreme rainfall variability makes evaluation of range renovation projects difficult. Results from least squares regression analysis of "paired" watersheds for other than very small watersheds, for example, are uncertain. The extreme rainfall variability also enhances the probable value of even small increases in available soil water during critically dry seasons.

\section{Watershed Description}

The 227-ha study watershed (63004) lies north of Tombstone, Arizona, on the north boundary of the Walnut Gulch Experimental Watershed (Fig. 1). Watershed slopes vary up to $14 \%$; the average is about $9 \%$. The watershed is drained by well-defined incised sand-bottom channels in the lower one-third and broad swales with poorly defined shallow meandering channels in the upper two-thirds of the watershed. Headcuts separate the incised sandbottom channels from the swales.

Desert shrubs are the dominant vegetation consisting primarily of whitethorn (Acacia constricta Benth.), creosotebush (Larrea tridentata Sesse \& Moc. ex DC.), and tarbush (Flourensia cernua DC.). There are several patches of black grama grass (Bouteloua eriopoda Torr.) on the upper part of the watershed. The total vegetation canopy cover averages about $30 \%$.

Soils are gravelly to sandy loams. Upland soils are generally well-drained calcareous, gravelly loams (Rillito series) with an erosion pavement of $40 \%$ or greater on the soil surface. Soil in the swales and adjacent to the gullies is a sandy loam (Laveen series) with fine gravel on the surface. There has been no grazing on the watershed since 1960 .

\section{Treatment}

The 227-ha watershed was ripped on the contour in June 1965, immediately before the summer rainy season. A Jayhawk Soil Saver', a chisel with a 15-cm diameter varied spinner that fractures "The mention of commercially manufactured equipment does not imply endorsement
of the USDA over similar equipment not mentioned here. 


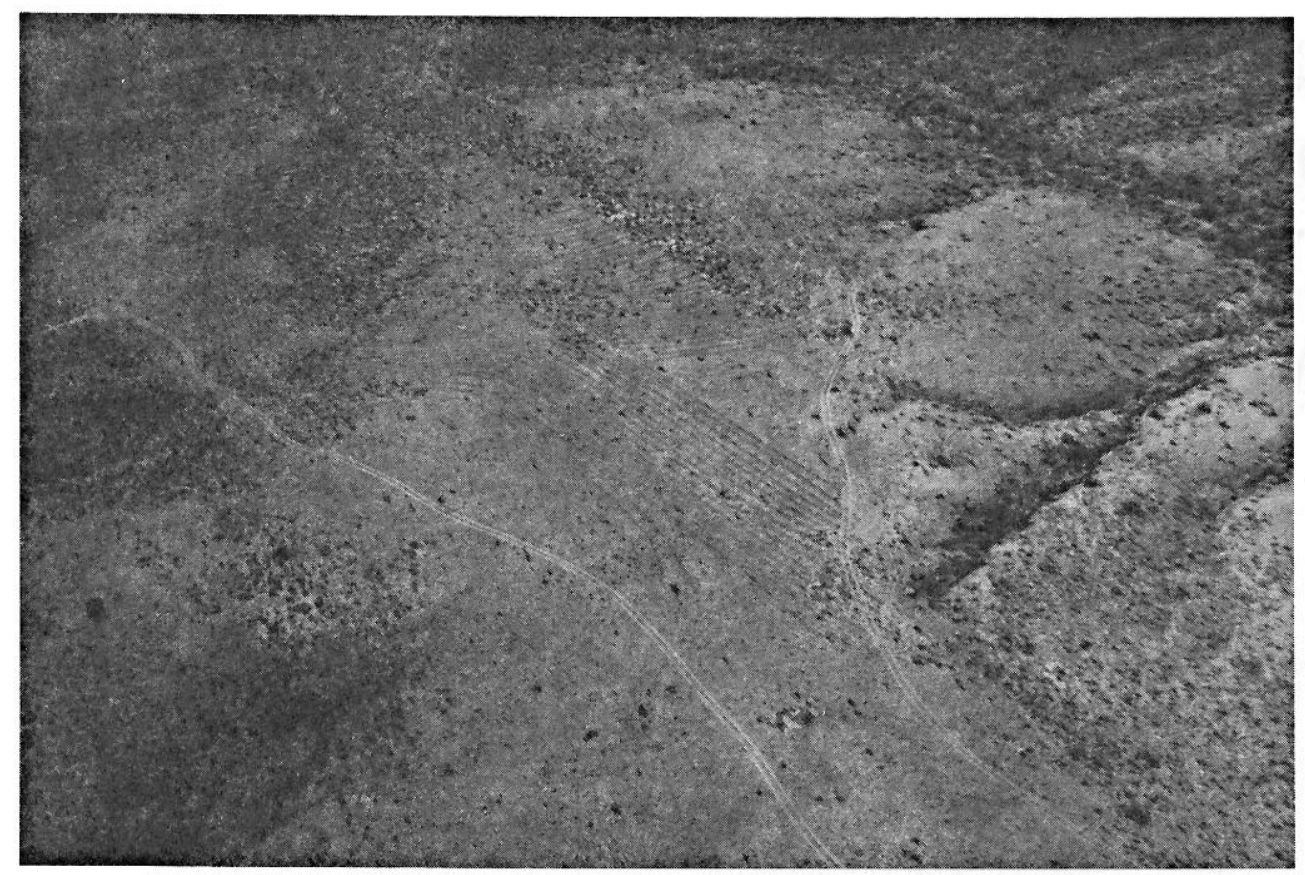

Fig. 3. Aerial view of Walnut Gulch 63004 following ripping in 1965.

were unreliable; possibly because of poorly designed runoff measuring structure. Based on correspondence between rainfall and runoff amounts, runoff records from 1965 to 1973 are considered fair to good; records from 1974 to the present are excellent.

\section{The Kinematic Cascade Model}

With the rapid advance in computer technology in recent years, more sophisticated mathematical models are now available for evaluating hydrologic changes with changing land uses including mechanical treatment of rangeland watersheds. One model, KINEROS, appears to be particularly well-suited for analyzing runoff hydrographs from rangeland watersheds which have undergone or are undergoing mechanical treatment.

The kinematic cascade model KINEROS (Kibler and Woolhiser 1970, Rovey et al. 1977, Lane and Woolhiser 1977, and Smith 1981), used in this study is versatile and sensitive to both rainfall and runoff characteristics. It is a well-tested, nonlinear, deterministic, distributed parameter model (Rovey et al. 1977). The model has been used effectively to estimate flood frequencies on a rangeland watershed (Osborn 1984) and as an aid to flood plain management (Osborn and Unkrich 1987). Inputs are: (1) hyetographs of actual or simulated rainfall; (2) watershed surface geometry and

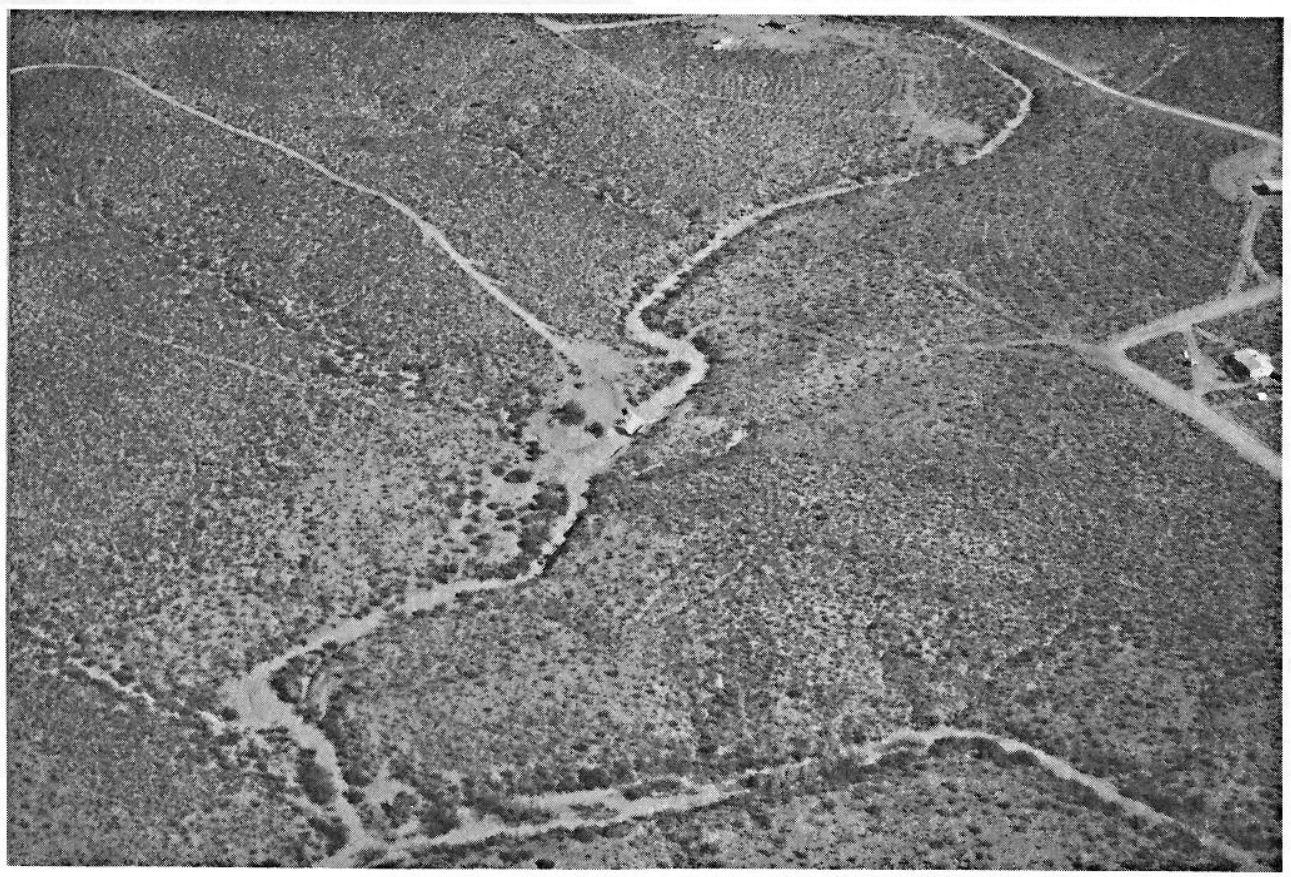

Fig. 4. Evidence of 1965 ripping Walnut Gulch 63004, photo taken in 1975. 


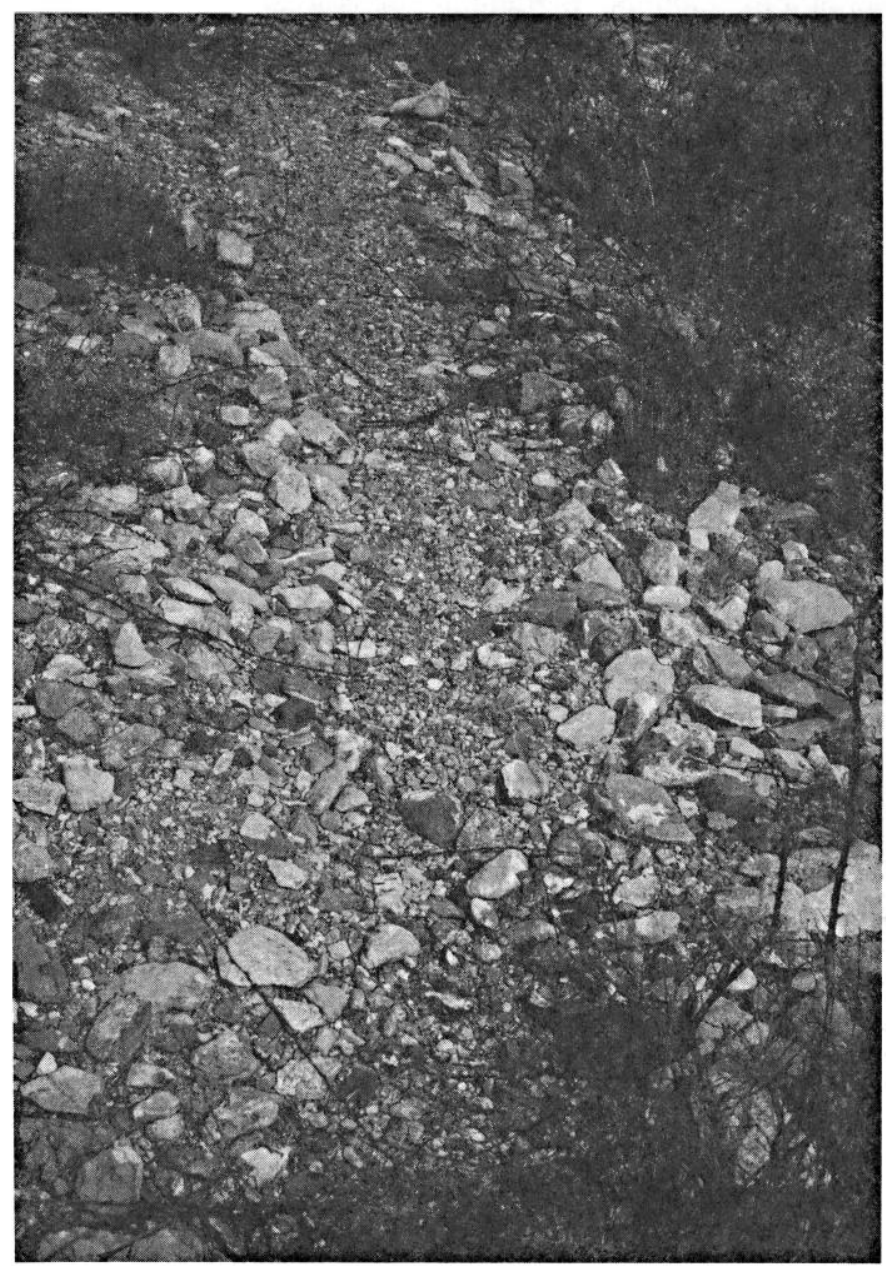

Fig. 5. Ground level evidence of ripping in 1985 on Walnut Gulch 63004.

topography; (3) watershed surface roughness parameters; (4) soil infiltration parameters; and, (5) channel parameters including hydraulic roughness, cross-section area, slope, and infiltration (Smith 1981).

For KINEROS, watershed 63004 was subdivided into 28 overland flow areas (planes) and 12 channels. These were numbered to correspond to the order of processing within the model program. Surface geometry of each plane and channel reach was determined from a topographic map using computer enhanced graphics. There are no significant water storage features (stock ponds, etc.) on the watershed.

Because of inadequate runoff records prior to the 1965 treatment, model parameters had to be adjusted based on studies of nearby watersheds, 63105 and 63011 (Fig. 1). Both 63105 and 63011 are also located on the north boundary of the Walnut Gulch experimental watershed. All 3 watersheds, 63105, 63011, and 63004, have similar elevations and aspects. Watershed 63011 (810 ha) has both brush and grass cover. It has 3 major branches: the north branch which is drained by an incised, sand-bottom channel almost to the headwaters; a central branch, which is almost entirely controlled by 2 stock ponds; and a south branch which is drained by an incised, sandbottom channel on the lower one-third of the drainage, and a swale on the upper two-thirds of the drainage (similar to 63004). Watershed $63105(0.25 \mathrm{ha})$ also has brush and grass cover with a very efficient small channel network to carry runoff to the watershed outlet. The sand-bottom channels on 63004 are not as extensive or as deep as on 63011. Greater runoff

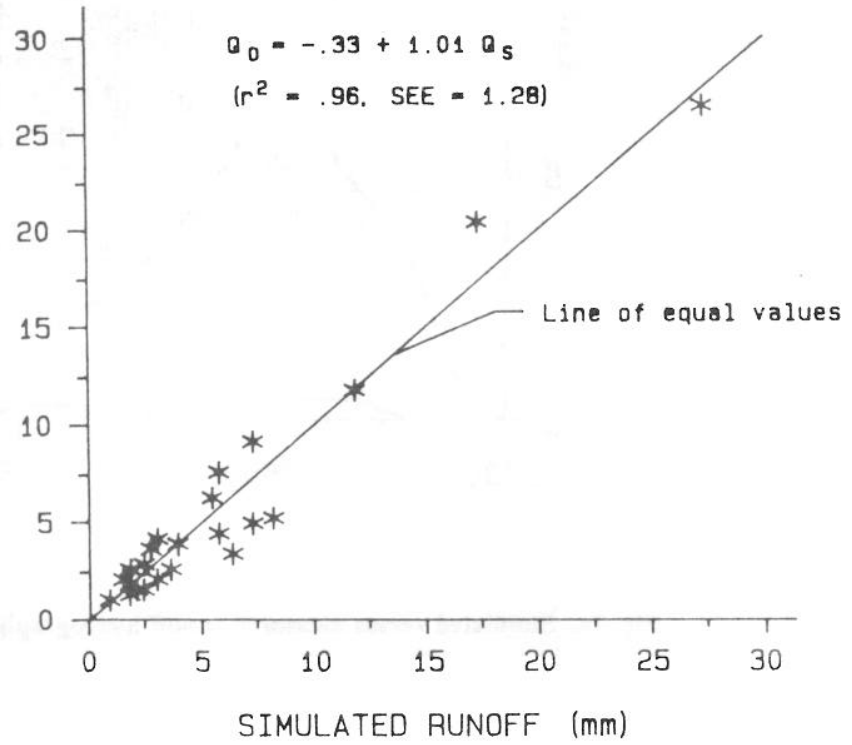

Fig. 6. Measured versus simulated runoff, Walnut Gulch 63011.

transmission losses in the channels are possible on 63011, and the differences in potential channel transmission losses between 63011 and 63004 had to be taken into account in adapting the channel parameters in KINEROS. All 3 watersheds have gravelly to sandy loam soils.

Correlations between observed and simulated runoff for 63011 using KINEROS were very good (Fig. 6). Equally good correlations were obtained for 63015 (not shown).

Based on the rainfall/runoff simulations of KINEROS for 63105 and 63011 , the parameter values for 63004 were assumed as:

$\mathrm{ROC}=0.4$ (volume fraction of rock in underlying soil)

$A=50 \mathrm{~mm}$ (sorptivity for a sandy loam, Rawls et al. 1982)

RECS $=0.02 \mathrm{~mm}$ (recession parameter for shallow flow)

FMIN $=12 \mathrm{~mm} /$ hour (minimum infiltration rate)

$\mathrm{n}_{\mathrm{p}}=0.07$ (Manning's $\mathrm{n}$ for overland flow areas)

$\mathrm{n}_{\mathrm{c}}=0.25$ (Manning's $\mathrm{n}$ for incised channels) and

$\mathrm{n}_{\mathrm{s}}=0.35$ (Manning's $\mathrm{n}$ for swales).

Rainfall/runoff relationships for 63011 and 63105 , based on KINEROS simulations, indicated that runoff peaks and volumes were insensitive to antecedent soil moisture conditions for all but the smallest events. Therefore, antecedent soil relative saturation (SI) was set to 0.5 for all events. On the other hand, runoff volumes, and to a lesser extent runoff peaks, were sensitive to antecedent moisture conditions of the channels for all flows. When channels are dry prior to an event, there is significant transmission loss, particularly in the rising limb of the hydrograph. Once the channels are saturated, runoff moves more rapidly through the channel system, and peaks and volumes are greater than would be measured for dry antecedent conditions.

\section{Analysis}

Runoff hydrographs, calibrated on runoff volume, of 63004 were simulated using KINEROS for all events with rainfall exceeding $12.5 \mathrm{~mm}$ at 2 or more raingages and rainfall intensities exceeding $25 \mathrm{~mm} / \mathrm{hr}$ for at least 10 minutes at 2 or more gages. Based on these criteria there were 41 significant $(Q \geq 0.25 \mathrm{~mm})$ simulated runoff events from 1965 through 1982 (Table 1). There were also 5 events in which significant runoff was measured but not simulated (Table 1). Isohyetal rainfall maps were drawn for all simulated runoff events with peaks of $3 \mathrm{~m}^{3} / \mathrm{sec}$ or greater. Four of the 19 major events between 1965 and 1982 were selected to illustrate the 


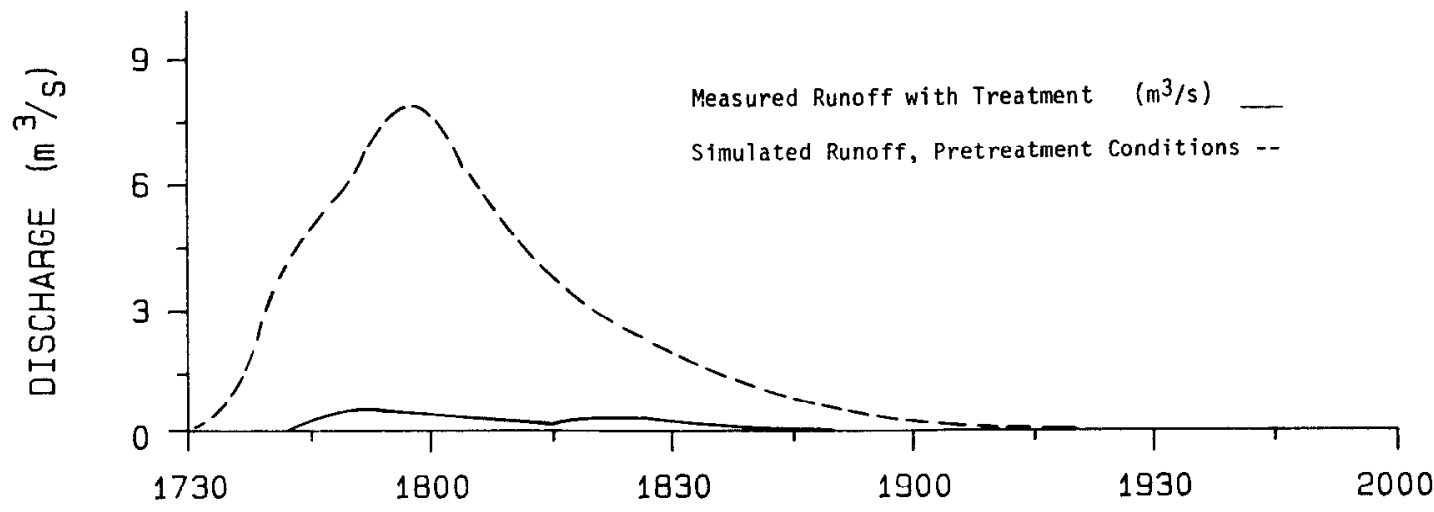

TIME

Fig. 7a. Simulated versus measured runoff hydrographs for 25 August 1968, Walnut Gulch 63004.

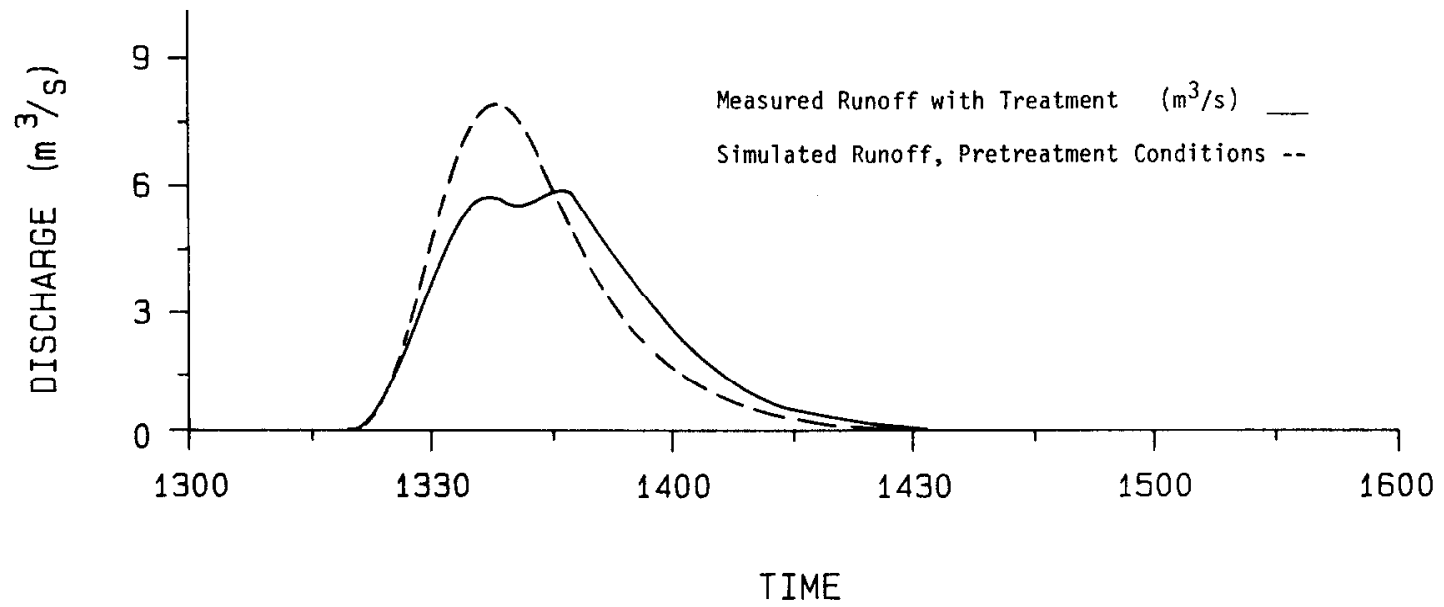

Fig. 7b. Simulated versus measured runoff hydrographs for 8 September 1970, Walnut Gulch 63004.

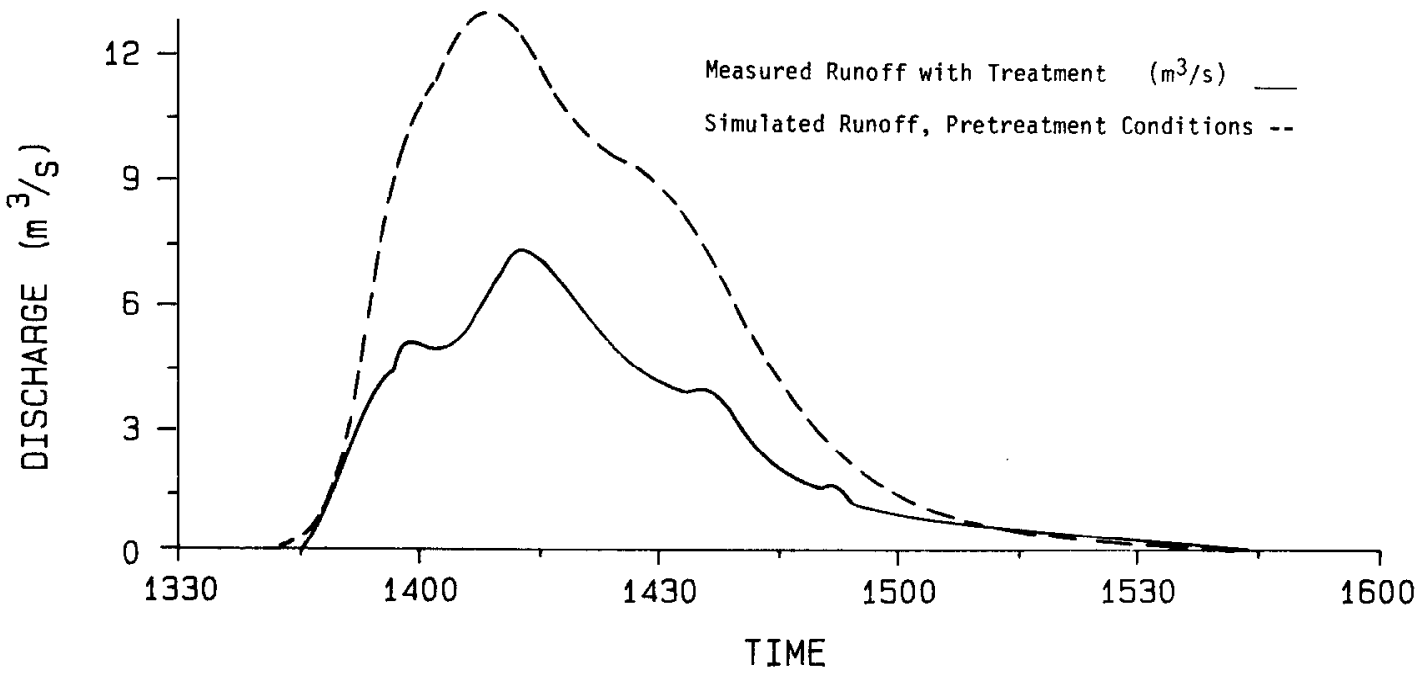

Fig. 7c. Simulated versus measured runoff hydrographs for 17 July 1975, Walnut Gulch 63004 . 
Table 1. Measured and simulated storm runoff for Walnut Gulch 63004, 1965-1982.

\begin{tabular}{|c|c|c|c|c|c|c|c|c|}
\hline \multicolumn{3}{|c|}{ Date } & \multirow[b]{2}{*}{$\mathbf{P}_{\mathbf{T}}$} & \multirow[b]{2}{*}{$\mathbf{I}_{30}$} & \multicolumn{2}{|c|}{ Measured } & \multicolumn{2}{|c|}{ Simulated } \\
\hline Yr & Mon & Day & & & $Q_{P}$ & Q & $Q_{P}$ & $Q$ \\
\hline & & & $(\mathrm{mm})$ & $(\mathrm{mm} / \mathrm{hr})$ & $\left(\mathrm{m}^{3} / \mathrm{s}\right)$ & $(\mathrm{mm})$ & $\left(\mathrm{m}^{3} / \mathrm{s}\right)$ & $(\mathrm{mm})$ \\
\hline \multirow[t]{3}{*}{65} & Jul & 27 & 18.3 & 34.5 & 0.0 & 0.0 & 2.61 & 1.90 \\
\hline & Aug & 13 & 15.2 & 25.9 & 0.37 & 0.15 & 1.64 & 0.84 \\
\hline & Sep & 04 & 15.5 & 22.9 & 0.0 & 0.0 & 1.33 & 0.86 \\
\hline \multirow[t]{5}{*}{66} & Jul & 28 & 20.8 & 32.3 & 0.0 & 0.0 & 2.78 & 1.73 \\
\hline & & 29 & 18.5 & 36.8 & 0.40 & 0.13 & 6.09 & 3.61 \\
\hline & Aug & 13 & 13.7 & 26.2 & 0.0 & 0.0 & 0.85 & 0.53 \\
\hline & & 16 & 15.0 & 20.3 & 0.51 & 0.20 & 2.18 & 1.73 \\
\hline & Sep & 11 & 17.5 & 32.5 & 0.14 & 0.08 & 4.13 & 2.54 \\
\hline \multirow[t]{3}{*}{67} & Jul & 11 & 11.7 & 22.4 & 0.0 & 0.0 & 0.91 & 0.66 \\
\hline & Sep & 10 & 12.7 & 17.3 & 0.08 & 0.03 & 0.57 & 0.33 \\
\hline & & 24 & 11.9 & 17.8 & 0.74 & 0.56 & 0.57 & 0.61 \\
\hline \multirow[t]{3}{*}{68} & Jul & 02 & 19.6 & 29.2 & 0.0 & 0.0 & 2.75 & 1.70 \\
\hline & Aug & 25 & 26.4 & 45.7 & 0.48 & 0.36 & 7.76 & 7.57 \\
\hline & & 31 & 21.6 & 40.6 & 0.62 & 0.66 & 4.81 & 4.42 \\
\hline 69 & Sep & 15 & 15.5 & 24.9 & 0.08 & 0.05 & 0.62 & 0.41 \\
\hline \multirow[t]{2}{*}{70} & Aug & 10 & 17.8 & 30.2 & 1.30 & 0.81 & 4.16 & 3.48 \\
\hline & Sep & 08 & 21.1 & 37.6 & 5.75 & 4.83 & 7.84 & 4.95 \\
\hline \multirow[t]{5}{*}{71} & Jul & 23 & 28.7 & 50.5 & 2.66 & 3.48 & 3.20 & 4.44 \\
\hline & & 24 & 20.1 & 39.9 & 2.80 & 3.43 & 2.83 & 3.28 \\
\hline & Aug & 10 & 32.2 & 64.5 & 11.36 & 9.80 & 16.82 & 13.18 \\
\hline & & 12 & 26.4 & 39.9 & 7.14 & 6.98 & 7.87 & 6.63 \\
\hline & & 18 & 21.8 & 41.1 & 3.94 & 4.39 & 2.83 & 3.25 \\
\hline 72 & Sep & 06 & 16.8 & 32.5 & 1.33 & 1.07 & 0.54 & 0.25 \\
\hline 73 & Jul & 27 & 22.4 & 39.4 & 2.83 & 2.13 & 4.42 & 4.14 \\
\hline 74 & Aug & 01 & 23.9 & 44.2 & 1.95 & 1.70 & 9.63 & 5.79 \\
\hline \multirow[t]{2}{*}{75} & Jul & 17 & 38.6 & 62.5 & 7.14 & 7.95 & 12.91 & 15.11 \\
\hline & Sep & 13 & 29.0 & 56.6 & 1.78 & 2.39 & 11.67 & 9.25 \\
\hline 76 & Sep & 06 & 18.5 & 25.9 & 0.65 & 0.46 & 0.06 & 0.03 \\
\hline \multirow[t]{6}{*}{77} & Jun & 22 & 13.7 & 17.5 & 1.59 & 1.14 & 0.28 & 0.20 \\
\hline & Jul & 31 & 15.7 & 20.3 & 0.34 & 0.33 & 0.85 & 0.69 \\
\hline & Aug & 15 & 22.6 & 39.6 & 3.71 & 2.79 & 6.15 & 4.22 \\
\hline & Sep & 01 & 24.4 & 21.8 & 0.96 & 2.74 & 2.04 & 1.73 \\
\hline & & 05 & 12.7 & 16.8 & 0.88 & 1.24 & 0.51 & 0.61 \\
\hline & & 26 & 51.0 & 57.9 & 6.26 & 11.58 & 5.89 & 13.54 \\
\hline \multirow[t]{2}{*}{78} & Jul & 25 & 27.9 & 50.3 & 1.02 & 1.24 & 8.01 & 7.62 \\
\hline & Aug & 01 & 16.5 & 32.3 & 0.45 & 0.33 & 1.81 & 1.57 \\
\hline 79 & Aug & 18 & 11.7 & 14.7 & 0.17 & 0.18 & 0.74 & 0.51 \\
\hline \multirow[t]{2}{*}{80} & Jul & 30 & 15.5 & 31.0 & 1.05 & 0.43 & 2.95 & 1.50 \\
\hline & Aug & 24 & 21.8 & 36.6 & 0.45 & 0.61 & 0.68 & 0.51 \\
\hline \multirow[t]{3}{*}{81} & Jul & 19 & 14.5 & 23.1 & 0.74 & 0.69 & 0.0 & 0.0 \\
\hline & & 28 & 23.1 & 17.8 & 0.40 & 0.53 & 0.14 & 0.08 \\
\hline & & 30 & 16.5 & 15.7 & 0.54 & 1.07 & 0.74 & 0.36 \\
\hline \multirow[t]{4}{*}{82} & Jul & 20 & 16.5 & 31.0 & 0.85 & 0.74 & 0.79 & 0.53 \\
\hline & Aug & 23 & 15.7 & 21.1 & 0.85 & 0.43 & 0.0 & 0.0 \\
\hline & Sep & 10 & 23.1 & 29.0 & 0.65 & 1.14 & 0.85 & 0.86 \\
\hline & & 11 & 21.6 & 29.7 & 2.92 & 3.15 & 5.18 & 4.62 \\
\hline
\end{tabular}

initial impact and long-term effect in reducing runoff from the ripped watershed (Fig. 7a-c).

Visual inspection of hydrographs and isohyetal maps along with Table 1, provide an excellent chronology of watershed hydrologic change. There was less than $0.25 \mathrm{~mm}$ of measured runoff from 63004 in 1965 whereas KINEROS simulated about $3.6 \mathrm{~mm}$ for pretreatment watershed. Total average rainfall over the watershed was $49 \mathrm{~mm}$ for the 3 events; simulated runoff was about $10 \%$ of storm rainfall. Measured runoff through August 1970 was only about $3 \mathrm{~mm}$ compared to simulated runoff of $33 \mathrm{~mm}$. Comparisons of simulated and measured hydrographs for the 25 Aug. 1968 storm (Fig. 7a) indicate the extent of treatment effects on runoff. Measured hydrographs were greatly reduced and flow through the system was greatly retarded relative to the simulations. The 25 Aug. 1968 storm was an unusual event. The storm moved slowly "up" the watershed. Apparently, the lower end of the watershed was disturbed enough to significantly reduce runoff, and the upper

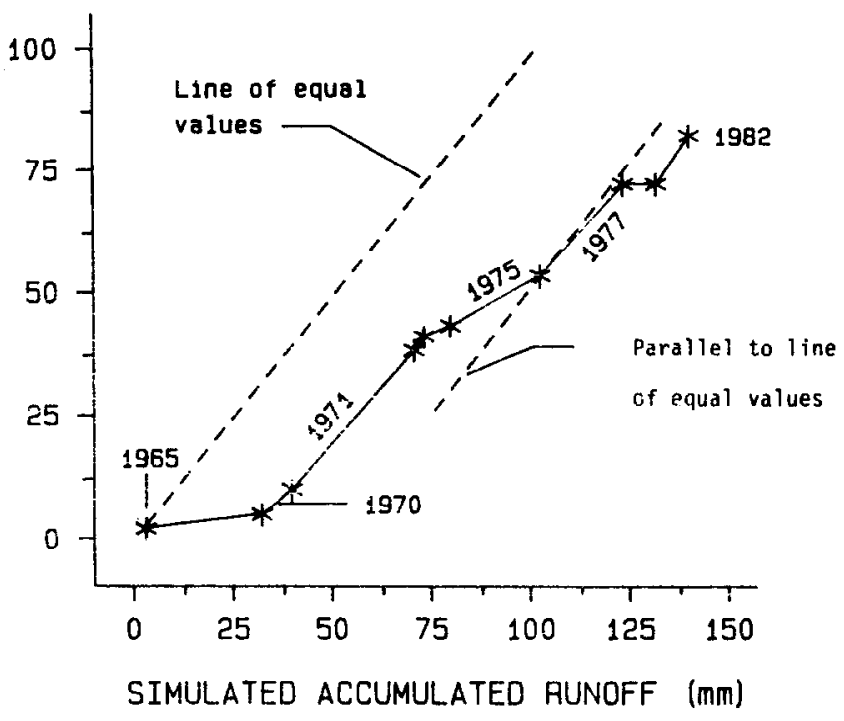

Fig. 8. Comparison of measured and simulated runoff for Walnut Gulch 63004, 1965-1982.

two-thirds produced practically no runoff at all. All the major events through 10 Aug. 1970, except for 25 Aug. 1968, were centered on the watershed, with potential runoff coming primarily from the swale drainages.

The storm of 8 Sept. 1970, centered near the watershed outlet in the partially treated area, produced the first significant measured runoff from the watershed since the 1965 treatment (Fig. 7b). Also, it may have been that the earlier storms on the lower end of the watershed on 25 Aug. 1968 and 10 Aug. 1970 had reduced the effectiveness of the ripping. This single event in 1970 plus significant runoff in 1971 was suggested as evidence that the watershed might have returned to its pretreatment condition (Simanton et al. 1978).

However, comparison of measured and simulated events in 1973,1974 , and 1975 suggested that the treatment was still effective (Fig. 7c). Measured runoff for 1973 through 1975 was about 14

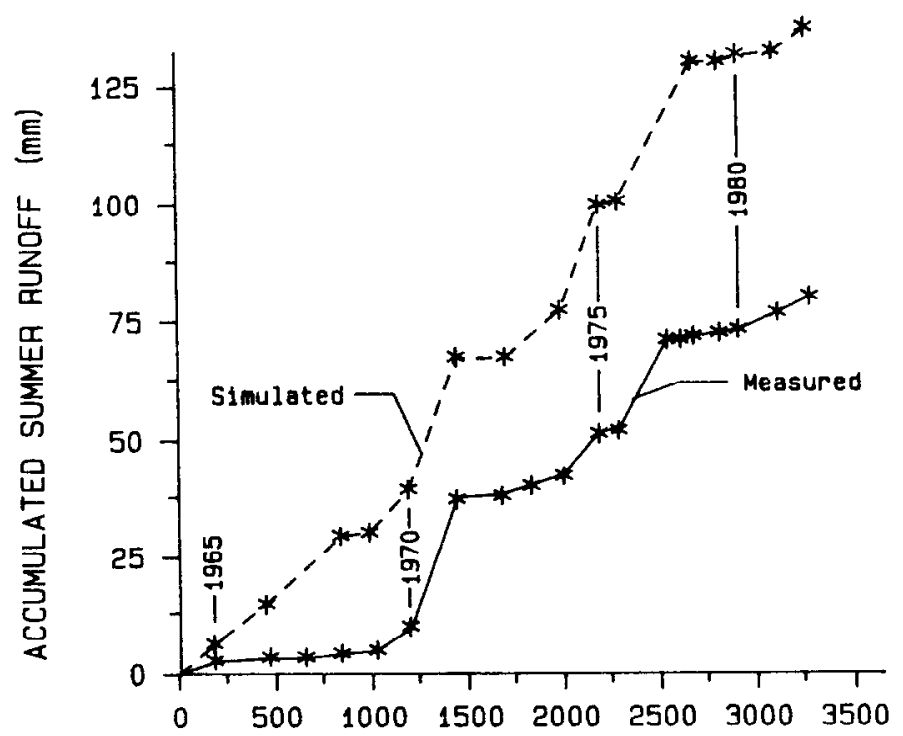

ACCUMULATED SUMMER RAINFALL $(\mathrm{mm})$

Fig. 9. Simulated versus measured runoff for Walnut Gulch 63004, 1965-1982. 
Table 2. Comparison of measured and simulated runoff volumes for selected intervals, Walnut Gulch 63004, 1965-1982.

\begin{tabular}{|c|c|c|c|c|c|c|c|c|}
\hline & \multicolumn{2}{|c|}{$\begin{array}{c}\text { July } 1965- \\
\text { Aug. } 1970 \\
\end{array}$} & \multicolumn{2}{|c|}{$\begin{array}{c}\text { Sep. } 1970- \\
\text { July } 1978\end{array}$} & \multicolumn{2}{|c|}{$\begin{array}{l}\text { Aug. } 1978 \text { - } \\
\text { Sep. } 1982 \\
\end{array}$} & \multicolumn{2}{|c|}{ Total } \\
\hline & $\begin{array}{c}\text { Run- } \\
\text { off }\end{array}$ & $\begin{array}{l}\text { Rain- } \\
\text { fall }\end{array}$ & $\begin{array}{c}\text { Run- } \\
\text { off }\end{array}$ & $\begin{array}{c}\text { Rain- } \\
\text { fall }\end{array}$ & $\begin{array}{c}\text { Run- } \\
\text { off }\end{array}$ & $\begin{array}{c}\text { Rain- } \\
\text { fall }\end{array}$ & $\begin{array}{c}\text { Run- } \\
\text { off }\end{array}$ & $\begin{array}{c}\text { Rain- } \\
\text { fall }\end{array}$ \\
\hline & $(\mathrm{mm})$ & $(\%)$ & $(\mathrm{mm})$ & $(\%)$ & $(\mathrm{mm})$ & $(\%)$ & $(\mathrm{mm})$ & $(\%)$ \\
\hline Measured & 3.05 & 4 & 69.6 & 85 & 9.40 & 11 & 82.30 & 100 \\
\hline Simulated & 33.50 & 23 & 98.0 & 69 & 10.67 & 8 & 142.24 & 100 \\
\hline
\end{tabular}

$\mathrm{mm}$, whereas simulated runoff was about $33 \mathrm{~mm}$ (Table 1 ). In the relatively wet year, 1977, simulated runoff approximated measured runoff. However, runoff on 25 July 1978 (not shown) indicated that the 1965 treatment was still effective. The last major event, 11 Sept. 1982, also produced less runoff than was simulated.

Comparison of measured and simulated accumulative runoff (Fig. 8) clearly shows the effect of ripping on runoff from 1965 through 1969. Differences appear to be meaningful from 1970 through 1982, but are not as obvious as were the differences between 1965 and 1970. From 1971 through 1982, except for 1975 and 1978, the measured and simulated runoff volumes are not too dissimilar. Plotting accumulated summer rainfall against accumulated summer runoff from 1965 through 1982 leads to the same conclusion (Fig. 9).

Measured runoff from July 1965 through August 1970, was 3 $\mathrm{mm}$ as compared to $33 \mathrm{~mm}$ of simulated runoff (Table 2). Measured runoff from September 1970, through July 1978, was $70 \mathrm{~mm}$ compared to $98 \mathrm{~mm}$ of simulated runoff (Table 2). From August 1978, through 1982, measured and simulated runoff were $9 \mathrm{~mm}$ and $11 \mathrm{~mm}$, respectively. Based on the differences between simulated and measured runoff volumes, about $60 \mathrm{~mm}$ of rainfall which would have otherwise passed through the watershed outlet were retained on the watershed from 1965 through 1982 . Both aerial and ground photos suggest that the additional moisture was retained at or near the ripped contour.

The results of a simple procedure to compare measured and simulated runoff volumes are shown in Table 3 . The $95 \%$ confidence interval for the mean event runoff volume is $\Theta \pm t$, where

$$
\begin{aligned}
\overline{\mathbf{Q}} & =\text { the simulated mean runoff volume }(\mathrm{mm}) \\
\mathbf{t} & =\text { students } \mathrm{t} \text { at the } 0.975 \text { level, } \\
\mathbf{S}_{\mathbf{Q}} & =\text { standard deviation of runoff volumes }(\mathrm{mm}), \text { and } \\
\mathbf{n} & =\text { number of events }
\end{aligned}
$$

\begin{tabular}{|c|c|c|c|c|c|c|c|}
\hline \multicolumn{4}{|c|}{ Peak Discharges } & \multicolumn{4}{|c|}{ Runoff Volumes } \\
\hline \multicolumn{2}{|c|}{ Measured } & \multicolumn{2}{|c|}{ Simulated } & \multicolumn{2}{|c|}{ Measured } & \multicolumn{2}{|c|}{ Simulated } \\
\hline Date & Peak & Date & Peak & Year & Volume & Year & Volume \\
\hline & $\left(\mathrm{m}^{3} / \mathrm{s}\right)$ & & $\left(\mathrm{m}^{3} / \mathrm{s}\right)$ & & $(\mathrm{mm})$ & & $(\mathrm{mm})$ \\
\hline 10 Aug 71 & 11.36 & 10 Aug 71 & 16.82 & 1971 & 28.10 & 1971 & 30.78 \\
\hline $17 \mathrm{Jull} 75$ & 7.14 & 17 Jul 75 & 12. & 1977 & & 1975 & 36 \\
\hline 12 Aug 71 & 7.14 & 13 Sep 75 & 11.67 & 1975 & 10.34 & 1977 & 20.98 \\
\hline $26 \operatorname{Sep} 77$ & 6.26 & 01 Aug 74 & & 1970 & 5.64 & 1968 & 13.69 \\
\hline 08 Sep 70 & 5.75 & $25 \mathrm{Jul} 78$ & 8.01 & 1982 & 5.46 & 1966 & 10.13 \\
\hline 18 Aug 71 & 3.94 & 12 Aug 71 & 7.87 & 1981 & 2.39 & 1978 & 9.17 \\
\hline 15 Aug 77 & 3.71 & 08 Sep 70 & 7.84 & 1973 & 2.13 & 1970 & 8.43 \\
\hline 11 Sep 82 & 2.92 & 25 Aug 68 & 7.76 & 1974 & 1.70 & 1982 & 6.02 \\
\hline 27 Jul 73 & 2.83 & 15 Aug 77 & 6.15 & 1978 & 1.57 & 1974 & 5.79 \\
\hline $24 \mathrm{Jul} 71$ & 2.80 & $29 \mathrm{Jul} 66$ & 6.09 & 1980 & 1.24 & 1973 & 4.14 \\
\hline $23 \mathrm{Jul} 71$ & 2.66 & 26 Sep 77 & 5.89 & 1972 & 1.07 & 1965 & 3.61 \\
\hline 01 Aug 74 & 1.95 & $11 \mathrm{Sep} 82$ & 5.18 & 1968 & 1.02 & 1980 & 2.01 \\
\hline 13 Sep 75 & 1.7 & 31 Aug & 4.8 & 1967 & 0.6 & 1967 & 1.6 \\
\hline 22 Jun 77 & 1.59 & 27 Jul 73 & 4.4 & 1976 & 0.46 & 1969 & 0.53 \\
\hline 06 Sep 72 & 1.33 & 10 Aug 70 & 4.16 & 1966 & 0.41 & 1979 & 0.51 \\
\hline 10 Aug 70 & 1.30 & 11 Sep 66 & 4.13 & 1979 & 0.18 & 1981 & 0.43 \\
\hline $30 \mathrm{Jul} 80$ & 1.05 & $23 \mathrm{Jul} 71$ & 3.20 & 1965 & 0.15 & 1972 & 0.25 \\
\hline 25 Jul 78 & 1.02 & $30 \mathrm{Jul} 80$ & 2.95 & 1969 & 0.05 & 1976 & 0.03 \\
\hline
\end{tabular}

Table 4. Runoff peaks and volumes ranked by magnitude, Walnut Gulch 63004, 1965-1982.

Based on this test, the measured and simulated runoff volumes were significantly different for the period July 1965 through Aug. 1970, and not significant after Aug. 1970. When the 18 largest measured and simulated peaks were ranked, the differences also were striking (Table 4). There were 18 simulated peaks over 2.8 $\mathrm{m}^{3} / \mathrm{s}$ as compared to 8 measured peaks over $2.8 \mathrm{~m}^{3} / \mathrm{s}$. Volumes were also affected by the treatment (Table 4).

\section{Discussion}

Mechanical ripping of Walnut Gulch watershed 63004 in 1965 greatly reduced runoff for at least 5 years. Based on storm simulations using a kinematic cascade rainfall/ runoff model, KINEROS, there was an apparent continued reduction in runoff through the 1970 's, and possibly into the 1980 's. Simulated hydrographs were assumed to represent the watershed as if it had not been treated. Because model parameters, by necessity, were based on evaluations of neighboring watersheds, the magnitude of the treatment effects after 1970 is somewhat uncertain. However, visual evidence

\begin{tabular}{|c|c|c|c|c|c|c|c|c|c|c|}
\hline \multirow[b]{3}{*}{ Period } & \multirow{3}{*}{$\begin{array}{c}\text { Number } \\
\text { of } \\
\text { Events }\end{array}$} & \multirow{3}{*}{$\begin{array}{l}\text { Precip. } \\
\qquad \overline{\mathrm{P}}\end{array}$} & \multicolumn{6}{|c|}{ Runoff Volume } & \multirow{3}{*}{$\begin{array}{l}\text { Confidence } \\
\text { Limits } \\
\underline{\underline{S_{Q}}} \\
\pm \mathrm{t} \sqrt{n}\end{array}$} & \multirow[b]{3}{*}{ Significance } \\
\hline & & & \multicolumn{3}{|c|}{ Measured } & \multicolumn{3}{|c|}{ Simulated } & & \\
\hline & & & $\mathrm{Q}_{\mathrm{T}}$ & $\overline{\mathbf{Q}}$ & $S_{Q}$ & $\mathrm{Q}_{\mathrm{T}}$ & $\overline{\mathbf{Q}}$ & $S_{Q}$ & & \\
\hline $\begin{array}{l}\text { July } 1965- \\
\text { Aug. } 1970\end{array}$ & 16 & 18 & 3 & 0.2 & $\begin{array}{l}(\mathrm{mm})-- \\
0.2\end{array}$ & 33 & 2.1 & 1.9 & 1.0 & $*$ \\
\hline $\begin{array}{l}\text { Sep. 1970- } \\
\text { July } 1978\end{array}$ & 19 & 25 & 53 & 2.8 & 3.2 & 87 & 4.6 & 4.0 & 1.9 & NS \\
\hline $\begin{array}{l}\text { Aug. 1978- } \\
1982\end{array}$ & 11 & 18 & 9 & 0.8 & 0.8 & 10 & 1.0 & 1.3 & 0.9 & NS \\
\hline $1965-1982$ & 46 & 20 & 65 & 1.4 & 2.6 & 130 & 2.8 & 3.3 & 1.0 & NS \\
\hline
\end{tabular}
indicates that the treatment may still have some effect on runoff as late as 1985, 20 years after the treatment. The visual and modeling

Table 3. Differences between measured and simulated runoff events for selected intervals, Walnut Gulch 63004, $1965-1982$.

$\overline{\mathbf{P}}=$ average storm rainfall $(\mathrm{mm})$

$Q_{\mathrm{T}}=$ total storm runoff $(\mathrm{mm})$

$\bar{Q}=$ average storm runoff $(\mathrm{mm})$

$S_{Q}=$ Standard deviation of runoff volumes $(\mathrm{mm})$

= significant at $95 \%$

NS $=$ Not significant 
evidences are compatible.

The longevity of the effects of ripping Walnut Gulch 63004 is at least partially the result of the semiarid environment. Runoff producing rainfall was below average during the 5 years following treatment. Small runoff producing events are the rule, rather than the exception on Walnut Gulch. If an exceptional event (the 100year storm) had occursed soon after the ripping, breaks in the contour dikes could have developed, negating the effect of the ripping. Since there were no large events, the contour dikes degraded more slowly and provided a long term "roughness" and some storage, particularly on the upper two-thirds of the watershed. Furthermore, the ripping effects may be greater for small events than large events.

Also, the watershed has not been grazed since 1960 . Grazing could have significantly affected the treatment, since cattle would have concentrated their grazing along the contour rips where there appeared to be better grass stands. The contour dikes would have been packed down by the cattle, greatly reducing the long-term impact of the ripping.

A further line of study would be how to best simulate the ripped watershed with a model such as KINEROS. The ripping initially provided additional surface and below surface storage capacity which might be simulated as drier antecedent soil moisture conditions. The contour rips could also be considered in the terms of added roughness, and an increase in Manning's $n$. The ripping might also have increased final infiltration rates and closed off many small gullies and rills which greatly reduced runoff efficiency.

\section{Conclusions}

The kinematic cascade model KINEROS was extremely useful in evaluating the hydrologic impact of ripping a rangeland watershed. Such models should be valuable particularly in cases such as this where pretreatment data are inadequate or nonexistent. Model simulations allow one to look at storm peaks and volumes, changing transmission loss rates on the watershed and within the channel, and accumulated seasonal runoff. This study also suggests that such models could be used to estimate hydrologic impacts in advance of rangeland treatments.

\section{Literature Cited}

Branson, F.A., R.F. Miller, and I.S. McQueen. 1966. Contour furrowing, pitting and ripping on rangelands of the Western United States. J. Range Manage. 19:182-190.

Dortignac, E.J., and W.C. Hickey, Jr. 1963. Surface runoff and erosion as affected by soil ripping. Proc. Federal Interagency Sedimentation Conf., 1963. USDA-SCS. Misc. Pub. 970:156-165.

Kibler, D.H., and D.A. Woolhiser. 1970. The kinematic cascade as a hydrologic model. Colorado State Univ., Hydrology Pap. 39.

Lane, L.J., and D.A. Woolhiser. 1977. Simplifications of watershed geometry affecting simulation of surface runoff. J. Hydr. 35:173-190.

Osborn, H.B. 1968. Persistence of summer rainy and drought periods on a semiarid rangeland watershed. Bull. Inter. Assoc. Sci. Hydr. 13:14-19.

Osborn, H.B. 1983. Precipitation characteristics affecting hydrologic response of Southwestern rangelands. USDA-ARS ARM-W-34, U.S. Gov. Print. Off., Washington, D.C.

Osborn, H.B. 1984. Storm cell properties influencing runoff from small watersheds. Nat. Res. Counc., Trans. Res. Board. TRR 922:24-32.

Osborn, H.B., and E.M. Laursen. 1973. Thunderstorm runoff in southeastern Arizona. J. Hydr. Div. Amer. Soc. Civil Eng. 99(HY7):1129-1145.

Osborn, H.B., and C.L. Unkrich. 1987. Simulation of flood peaks and volumes by kinematic modeling: an aid to flood plains management, $p$. 140-143. In: Proc. Western State High Risk Flood Areas Symp. Assoc. of State Flood Plain Managers, Box 2051, Madison, Wis. 53701.

Rawls, W.J., D.C. Brakensiek, and K.E. Saxton. 1982. Estimation of soil water properties. Trans. Amer. Soc. Agr. Engr. 25(SW1982):1316-1320, 1328.

Richardson, C.W., E. Burnett, and R.W. Bovey. 1979. Hydrologic effect of brush control on Texas rangelands. Trans. Amer. Soc. Agr. Eng. 22:315-319.

Rovey, E.W., D.A. Woolhiser, and R.E. Smith. 1977. A distributed kinematic model of upland watersheds. Colorado State Univ., Hydrology Pap. 93.

Simanton, J.R., H.B. Osborn, and K.G. Renard. 1978. Hydrologic effects of rangeland renovation, p. 331-334. In: Proc. First Internat. Rangel. Congr. Soc. Range Manage.

Smith, R.E. 1981. A kinematic model for surface mine sediment yield. Trans. Amer. Soc. Agr. Eng. 24:1508-1519.

Smith, R.E., D.L. Chery, K.G. Renard, and W.R. Gwinn. 1982. Supercritical flow flumes for measuring sediment-laden flow. USDA-ARS Tech. Bull. 1655.

USDA. 1987. The Second RCA appraisal. Draft. Soil, water, and related resources on nonfederal land in the United States.

\section{Editor Address Change}

Please note a change of address for the editor. Send manuscripts to Gary Frasier, USDA-ARS, Crops Research Laboratory, 1701 Center Avenue, Fort Collins, Colo. 80526. Page proofs and orders for reprints should still be sent to the Society headquarters, 1839 York Street, Denver, Colorado 80206. 